\title{
Estimating the climate change consequences on the potential distribution of Culex pipiens L. 1758, to assess the risk of West Nile virus establishment in Chile
}

\author{
Estimando las consecuencias del cambio climático en la distribución potencial de Culex \\ pipiens L. 1758 para evaluar el riesgo de establecimiento del virus del Oeste del Nilo en Chile
}

\section{Daniela P. Figueroa ${ }^{1}$, Sergio Scott ${ }^{1}$, Christian R. González ${ }^{2,3}$, Gustavo Bizama ${ }^{1,4}$, Raúl Flores- Mara $^{5}$, Ramiro Bustamante ${ }^{6} \&$ Mauricio Canals ${ }^{7 *}$}

${ }^{1}$ Centro de Investigación Aplicada de Chile (CIACHI), Santiago, Chile.

'Instituto de Entomología, Universidad Metropolitana de Ciencias de la Educación, Santiago, Chile.

${ }^{3}$ Laboratorio Entomología Médica, Instituto de Salud Pública de Chile, Santiago, Chile.

${ }^{4}$ Laboratory for Research in Environmental Sciences (LARES), Faculty of Agricultural Sciences, Department of Environmental Sciences and Natural Renewable Resources, Universidad de Chile, Santiago, Chile.

${ }^{5}$ Facultad de Ciencias de la Salud, E.P. de Medicina Veterinaria y Zootecnia, Universidad Andina “Néstor Cáceres Velásquez", Puno, Perú.

${ }^{6}$ Departamento de Ciencias Ecológicas, Facultad de Ciencias, Universidad de Chile, Santiago, Chile.

${ }^{7}$ Departamento de Medicina y Programa de Salud ambiental, Escuela de Salud Pública, Facultad de Medicina, Universidad de Chile, Santiago, Chile.

*E-mail:mcanals@uchile.cl

\begin{abstract}
Climate change affects the dynamics of vector-borne diseases. Culex pipiens Linnaeus is the main vector of West Nile fever; a widely distributed arbovirus, it is continuously increasing its distribution. Using a species distribution model, maps of suitable habitats of $C x$. pipiens were generated for Chile in the current climate and three climate change scenarios, using global and regional georeferenced vector presence records as input, plus bioclimatic variables. Since this virus has not yet arrived in Chile, the purpose of this study is to anticipate potential risk areas and to prevent the establishment and spread of the virus. $C x$. pipiens is widely distributed in Chile. The suitable habitats in Chile were concentrated mostly from $32^{\circ}$ to $35^{\circ} \mathrm{S}$, increasing in future scenarios up to $113 \%$ in the northern zone and moving towards the mountains. This species conserves around $90 \%$ of its niche in the future, and shows a reduction of $11.4 \%$ in the severe climate change scenario. It is anticipated that Chile will experience an increase in the environmental suitability for $C x$. pipiens moving from the Andes to the coastal zone throughout the country, mainly in the center-south. This will raise the risk of local virus transmission if the virus is introduced to the country via diverse routes.
\end{abstract}

Keywords: MaxEnt, mosquitoes, species distribution models, vector-borne diseases.

\section{RESUMEN}

El cambio climático afecta la dinámica de las enfermedades transmitidas por vectores. Culex pipiens Linnaeus es el vector principal de la fiebre del Nilo Occidental, un arbovirus que aumenta continuamente su distribución. Usando un modelo de distribución de especies, se generaron mapas hábitats favorables para Cx. pipiens en los escenarios de cambio climático actuales y tres futuros. Se utilizaron registros de presencia de vectores georreferenciados globales y regionales como entrada, más un conjunto de variables bioclimáticas. Dado que este virus aún no ha llegado a Chile, el propósito de este estudio es anticipar áreas de riesgo potencial y prevenir el establecimiento y la propagación del virus. Cx. pipiens está ampliamente distribuido en Chile. Las mayores probabilidades de 
presencia en Chile se concentraron principalmente de $32^{\circ}$ a $35^{\circ} \mathrm{S}$, aumentando en escenarios futuros hasta el $113 \%$ en la zona norte y avanzando hacia la cordillera. Esta especie conserva alrededor del $90 \%$ de su nicho en el futuro y muestra una reducción del 11,4 \% en el escenario de cambio climático severo. Se propone que Chile experimentará un aumento en los hábitats favorables para Cx. pipiens, el vector clave del WNV, que se moverá desde los Andes a la zona costera en todo el país, principalmente en el centro-sur. Esto producirá un aumento en el riesgo de transmisión del virus local si se introduce en el país a través de diversas rutas.

Palabras clave: enfermedades transmitidas por vectores, MaxEnt, modelos de distribución de especies, mosquitos.

\section{INTRODUCTION}

West Nile Fever is a public health problem in several countries of the world. It is caused by an arbovirus belonging to the family Flaviviridae, genus Flavivirus (Brault 2009; Hernández et al. 2009; Weaver \& Reisen 2010; Paz \& Semenza 2013). It is appears as a mild flu and occasionally as a severe neuro-invasive disease, called West Nile encephalitis, that can occur with headache, high fever, neck stiffness, stupor, disorientation, coma, tremors, convulsions, muscle weakness and flaccid paralysis (Pradier et al. 2012). Since its identification in 1937, it has been isolated from all continents except Antarctica (Hernández et al. 2009; Weaver \& Reisen 2010). Its geographical distribution has expanded considerably in the last ten years, probably due to global trade, climate change, ecological factors and the emergence of new viral genotypes (Brault 2009; Weaver \& Reisen 2010; Chancey et al. 2015). This virus has two cycles of transmission: a primary enzootic cycle that occurs by transmitting the virus through the bite of an adult mosquito to susceptible bird species, resulting in virus amplification (Hernández et al. 2009; Paz \& Semenza 2013). A secondary cycle involves mosquitoes that feed on the blood of birds and mammals, which behave as bridge vectors that spread infection to equines and humans, among other vertebrates. It has been isolated from species of mosquitoes belonging to 12 different genera (Aedes Meigen, Aedeomyia Theobald, Anopheles Meigen, Coquillettidia Dyar, Culex Linnaeus, Culiseta Felt, Deinocerites Theobald, Mansonia Blanchard, Mimomyia Theobald, Orthopodomyia Theobald, Psorophora Robineau-Desvoidy and Uranotaenia Lynch Arribálzaga). Culex is the most important vector genus involved in its maintenance, amplification and transmission. The participation of $C x$. pipiens $L$. has been a common factor in the epidemic outbreaks that have occurred in different countries (Hernández et al. 2009).
Culex species are ornithophilic and anthropophilic, and cosmopolitan in the case of Cx. pipiens (Maciá et al. 1997; Salazar \& Moncada 2004; Harbach 2011). They are important transmitters of several arboviruses, dirofilariasis and avian malaria (Bueno Marí et al. 2008). Nine species have been recorded in Chile: $C x$. acharistus Root, $C x$. annuliventris Blanchard, Cx. apicinus Philippi, Cx. articularis Philippi, Cx. curvibrachius Angulo, Cx. dolosus Lynch Arribálzaga, Cx. plicatus Olivares, Cx. pipiens and Cx. quinquefasciatus Say, distributed throughout practically all the national territory (González \& Mac-Lean 2008). It is difficult to determine the species $C x$. pipiens; $C x$. molestus has been mentioned as a physiological variant of $C x$. pipiens and is currently recognized as one of the more than 30 synonyms of $C x$. pipiens. This variant is not present in Chile (Harbach 2012). Cx. quinquefasciatus is a valid species, which together with $C x$. pipiens, $C x$. australicus, and Cx. globocoxitus are part of the "pipiens subgroup" within the "pipiens Group". The morphological separation between Cx. quinquefasciatus and $C x$. pipiens is complicated; they are very similar morphologically, especially the adults.

Cx. pipiens has a particularly broad global distribution, which in the Americas ranges from $45^{\circ} \mathrm{N}$ to $40^{\circ} \mathrm{S}$, while in some areas of Europe it reaches up to $63^{\circ} \mathrm{N}$. It has also been cited for eastern and southern Africa and different areas of Australia, as well as Asia. Cx. pipiens has been collected in an extensive area of Chile that includes cities from Arica $\left(18^{\circ} 28^{\prime}\right.$ S) to Frutillar (41 $07^{\prime}$ S) (González \& Rada 2015). However, studies of the natural history and distribution of Culicidae in Chile are fragmented and incomplete, disregarding relevant aspects of taxonomy, biology and knowledge of the immature forms of the species and their association with adults, which could hinder proper treatment and combat if diseases transmitted by these mosquitoes arrive (González et al. 2005; González et al. 2017; Carvajal \& Faundez 2018). Recently the distributions of Aedes aegypti and Cx. quinquefasciatus 
were analyzed as potential vectors of the Zika virus, showing that $C$. quinquefasciatus had a more temperate distribution up to $42^{\circ}$ (Alaniz et al. 2019) while the risk involving $A$. aegypti is concentrated mainly in tropical latitudes to $35^{\circ}$ in both hemispheres. There are other studies of distribution in changing climates in A. aegypti and Cx. quinquefasciatus (Samy et al. 2016; Kamal et al. 2018) and others that emphasize local and anthropogenic factors such as vegetation and urbanization in the distribution of mosquitos (Sallam et al. 2016; 2017; Wiese et al. 2019).

Since climate has a key influence on the biology, physiology and abundance of mosquito vectors, which are very sensitive to climatic conditions at many stages of their life cycle (Pradier et al., 2012), it is important to know the niche and distribution of $C x$. pipiens in different current and future scenarios with climate change with the purpose of planning the health management practices to control and prevent the expansion of this species.

The objectives of this study were to estimate the effects of climate change on the potential distribution of $C x$. pipiens, in current climatic conditions and under three contrasting scenarios of climate change, in order to identify better the risk zones for the possible future establishment of WNV transmission in Chile.

\section{MATERIAL AND METHODS}

\section{Presence data}

A total of 4694 presence records of the species referred as $C x$. pipiens L. georeferenced worldwide were obtained from the Global Biodiversity Information Facility database (GBIF, http://www.gbif.org) and 106 from Chile from field sampling and data provided by the Institute of Public Health of Chile. In order to reduce the impact of spatial autocorrelation, a sub-sampling of global presences was obtained, eliminating duplicates and those presences separated by less than $10 \mathrm{~km}$, using R software (version 3.5.1). The total data to calibrate the models included 837 records, of which 50 belong to Chile.

\section{ENVIRONMENTAL LAYERS}

Bioclimatic variables were obtained from the Wordclim database (http://www.worldclim.org/), with a spatial resolution of 5 arc-minutes (ca. $9 \mathrm{~km}$ ) for current and future scenarios. We used three different climate change scenarios, from optimistic to pessimistic representative concentration pathways (RCPs): RCP 4.5, RCP 6.0 and RCP 8.5. These were based on 10 global climate models from: Beijing Climate Center, China Meteorological Administration (BCC-CSM1-1) (BC), National Center for Atmospheric Research (CCSM4)
(CC), NASA Goddard Institute for Space Studies (GISS-E2-R) (GS), National Institute of Meteorological Research/Korea Meteorological Administration (HadGEM2-AO) (HD), Institut Pierre-Simon Laplace (IPSL-CMSA-LR) (IP), Atmosphere and Ocean Research Institute (The University of Tokyo), National Institute for Environmental Studies, Japan Agency for Marine-Earth Science and Technology (MIROC-ESM-CHEM) (MI), (MIROC5) (MC), (MIROC-ESM) (MR), Meteorological Research Institute (MRI-CGCM3) (MG) and the Norwegian Climate Centre (NorESM1-M) (NO) to 2070 (average for 2061-2080) of global climate models (GCM).

This data set included a total of 19 bioclimatic variables, with temperature and precipitation information. Because the collinearity of variables may lead to over-adjustment in the models (Beaumont et al. 2009), using ENMTools 1.4.4 a sub-sample of bioclimatic variables obtained after a Pearson correlation test was selected ( $r$ < 0.70) (Warren et al. 2008). Four bioclimatic variables were selected by this criterion: (bio1) average annual temperature; (bio2) average diurnal temperature range; (bio12) annual precipitation and (bio15) seasonality of precipitation.

\section{CONSTRUCTION OF THE SPECIES DISTRIBUTION MODELS}

We used local presence to observe the effects of climate change. MaxEnt software 3.41 was utilized, a method that evaluates the probability of distribution of a species by estimating the probability distribution function of maximum entropy (Philips et al. 2006), using only linear, quadratic functions and product characteristics to avoid overadjustment of the model (Kumar et al. 2014). To regulate the excess of parameterization, $\beta=1$ was used (Phillips and Dudík, 2008). The threshold rule was applied: "10 percentile training presence"; $75 \%$ training data were used and the remaining $25 \%$ were used to check the model generated, with 50 replicates. The number of pseudo-absences used is equivalent to the number of presence records per species multiplied by 10 (Beaumont et al. 2009) for global and regional models. We used the PresenceAbsence package of $\mathrm{R}$ to choose the best model with the prevalence approach, average probability/suitability, sensitivity-specificity sum maximization approach, the sensitivity-specificity equality approach and the ROC plot-based approach (Liu et al. 2005). The pseudo-absences were resampled with ENMTools 1.4.4 with 10 replicates (Barbet-Massin et al. 2012).

\section{DISTRIBUTION STABILITY}

To analyze changes in distribution between current and future models, the areas in $\mathrm{km}^{2}$ were calculated with ArcGIS (10.1) and intersected maps were reclassified with DIVA-GIS with a cutoff threshold of 0.23. A similarity test was performed with 
ENMTools 1.4.4; the niche similarity test addresses whether the environmental niche occupied in one range is more similar to the one occupied in the other range than would be expected by chance (Broennimann et al. 2012).

\section{RESULTS}

All models proved to have excellent predictive performance (AUC > 0.9). The relative contributions of the environmental variables used for the model showed that annual mean temperature variables represent the highest contribution percentages for current and future models $(54.6 \%$ at present and $60 \%, 60.5 \%$ and $56 \%$ for scenarios RCP4.5, 6.0 and RCP8.5, respectively). According to the jackknife test, the best predictor variable for the distribution of $C_{x}$. pipiens was annual mean temperature, second was annual precipitation, followed by average daytime temperature range and finally the seasonality of precipitation.

The potential distribution of $C x$. pipiens in Chile (Fig. 1) showed that there is a high probability of presence in the south-central zone of Chile from $32^{\circ}$ to $35^{\circ} \mathrm{S}$ (Fig. 1A), increasing in future scenarios (Fig. $1 \mathrm{~B}, \mathrm{C}, \mathrm{D}$ ). The greatest expansion of the area of $113.84 \%\left(132551 \mathrm{~km}^{2}\right.$, red color Fig. 2) was found in the in the RCP 8.5 scenario, which had the highest probabilities $>0.8$, while in the RCP 4.5 scenario it expanded by $94.5 \%\left(110047 \mathrm{~km}^{2}\right.$, red color, Fig. $\left.2 \mathrm{~A}\right)$. An increase of $95.5 \%\left(111154 \mathrm{~km}^{2}\right)$ also occurs in the RCP 6.0 scenario (red color, Fig. 2B), mainly in the probabilities $>0.4$. The similarity test for present and future climates showed $85 \%, 84 \%$ and $77 \%$ in RCP 4.5, 6.0 and 8.5, respectively. Reduction areas (green color, Fig. 2) were 1.8, 2.1 and 11.4 $\%$ in RCP 4.5, 6.0 and 8.5, respectively.

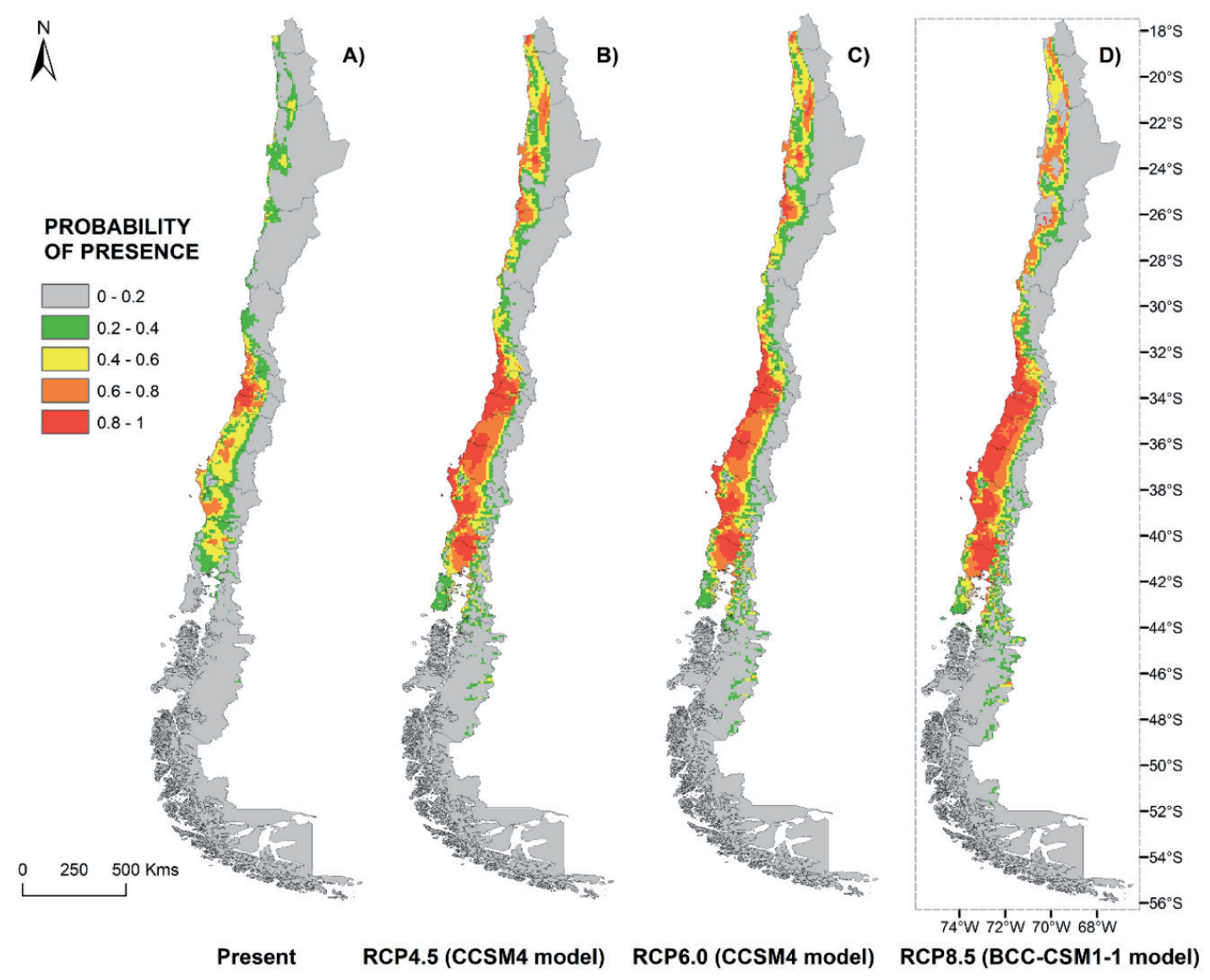

Figure 1. Models of potential distribution of the CX. pipiens group in Chile, current and future according to climate change scenarios. A: Current, B: RCP4.5, C: RCP6.0, D: RCP8.5. / Modelos de distribución potencial del grupo Cx. pipiens en Chile, actual y futuro según escenarios de cambio climático. A: actual, B: RCP4.5, C: RCP6.0, D: RCP8.5. 


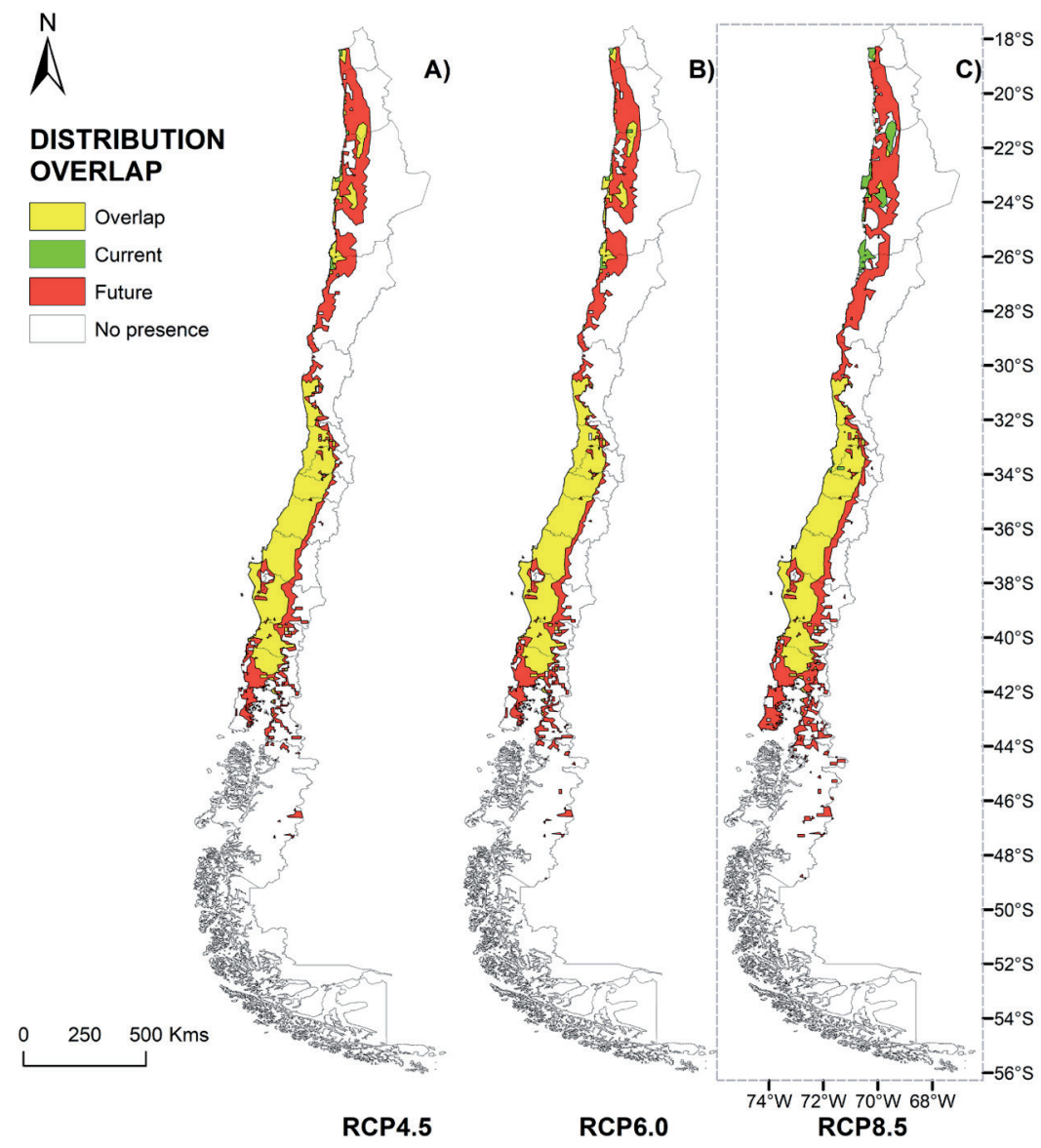

Figure 2. Overlap of current distribution area and different scenarios of climate change of the Cx. pipiens group. A: RCP 4.5, B: RCP 6.0, C: RCP 8.5. / Superposición del área de distribución actual y diferentes escenarios de cambio climático del grupo Cx. pipiens A: RCP 4.5, B: RCP 6.0, C: RCP 8.5.

\section{DISCUSSION}

The potential suitable distribution of $C x$. pipiens is widespread across the different ecological zones of continental Chile, which is consistent with the ecological preference and empirical geographic distribution of this species, Arica $\left(18^{\circ}\right.$ $28^{\prime}$ S) to Frutillar (4107' S) (González \& Rada 2015).

This study used bioclimatic variables to predict the distribution of $C_{x}$. pipiens; the main predictor of the distribution was the mean annual temperature. This agrees with Gardner et al. (2012), who found that high average daily temperatures favored the abundance of larvae of the $C x$. pipiens group, as they develop more rapidly in environments with higher aquatic and environmental temperatures. This is consistent with the microscale analysis performed by Figueroa et al. (2016) in three regions of Chile, where the temperature axis was a fundamental axis and positively correlated with the presence of this species. Paaijmans et al. (2010) reported that the relationship between mosquito development and temperature is generally one of the keys to understanding the dynamics and current and future distributions of vectorborne diseases. Many models use mean air temperature to estimate larval development times, and therefore adult vector density and/or disease risk.

The potential distribution of $C x$. pipiens will expand to a large extent in the future because it tends to adapt to optimal climatic conditions for its reproductive cycle (Gardner et al. 2012). A slight increase in rainfall in the northern zone of Chile would favor larval stages. Loss of up to $30 \%$ of precipitation in the south-central zone of Chile (IPCC, 2014) could explain the possible distribution increase in this area, because at present excess rain causes immature stages to be washed out (Geery \& Holub 1989; Gardner et al. 2012; Lebl et al. 2013). This increase in the area is mainly in the warm zone of Chile (north-central: $18-32^{\circ} \mathrm{S}$ ) and only a little in the cold zone of the southern Chile $\left(42-44^{\circ} \mathrm{S}\right)$. The expansion 
of suitable habitats to more southern latitudes found in our study may be due to the ability of $C_{x}$. pipiens to diapause and therefore extend its distribution to cold areas (Almirón and Brewer 1996). The expansion to warm areas agrees with studies that suggest that warmer conditions are drivers of mosquito abundance (McMichaael et al. 2011). However, in a related species, $C_{x}$. quiquefasciatus, other studies suggest a delay in the breeding season in areas with hot and dry spring and summer and suitability of occurrence in areas of low temperatures (Samy et al. 2016).

Species distribution models proved to be a good first approach to estimate the current and future potential distribution of the $C x$. pipiens group in Chile, a species that in the future could be infected by West Nile virus. However, the expansion of the vector is not the only factor for expansion of West Nile virus. It has been shown that the distribution of bird populations, urbanization and agriculture are related to the expansion of this problem (Kilpatrick 2011; Bradley et al. 2008; Wiese et al. 2019), as well as the underlying sociopolitical issues such as defective public health infrastructure (Gubler 2007) and poverty (Bhakat et al. 2014; Hernandez et al. 2018) in the regions of its expanse. For example, to understand better the expansion of Aedes albopictus into urban places it is important to consider the role of both environmental and neighborhood factors (Wiese et al. 2019). Environmental variables help to explain conditions associated with mosquitoes in suburban/ rural areas, while neighborhood factors are better able to explain mosquito habitats in urban places (Wiese et al. 2019). Another study emphasized that the distribution of WNV transmission is dependent on the mosquito vector and its ecological requirements, which vary from one place to another, showing that although precipitation of driest months was the best predicting variable for the density of $C_{x}$. nigripalpus, the distribution of $C x$. quinquefasciatus was more related to vegetation. Urbanization and vegetation were also highly relevant in predicting the suitability of this species (Sallam et al. 2016).

Limitations to this study are taxonomic, because in some old data the identification of $C x$. pipiens may be doubtful since it is difficult to differentiate from $C_{x}$. quinquefasciatus. Another limitation is that when we consider that the climatic variables are changing, the projection of the niche is conditioned by the local adaptation dilemma vs. niche fidelity or conservatism (Wiens et al. 2010). Niche conservatism, the tendency of a group to remain in its ancestral environment, is assumed in niche models. However, by contrast in some species dispersion may not be only a demographic response to the opportunity to colonize environments similar to their place of origin but also local adaptation may alter the fundamental niche, particularly when the invasion range is wide enough to encompass a wide spectrum of weather conditions.

The ecological maps produced can contribute meaningfully to the design and planning of mosquito surveillance programs by defining strategic areas for new collections and to control the possible expansion, especially in the case of poorly sampled regions. In this particular case the highest risk zones are currently from $30.5^{\circ}$ to $41^{\circ} \mathrm{S}$, where the mosquito would remain in the future. The monitoring of their populations should be focused in this zone to evaluate the risk of occurrence of arboviruses, thus optimizing the use of resources, minimizing the effort invested in surveillance and generating important contributions to decision/making and the adoption of preventive measures. The identification of areas potentially inhabited by the WNV vector is crucial for early response and prevention of a prospective epidemic in Chile. These results may be helpful in generating hypotheses and in identifying the appropriate conditions for WNV amplification and transmission if and when introduction occurs.

\section{ACKNOWLEDGMENTS}

This study was funded by the CONICYT PhD grant and Fund for Science and Technology of Chile: FONDECYT 1150514. We thank the valuable assistance of Professor Juan Sergio Figueroa, Sonia Pérez, Alfredo Navarrete, Álvaro Henríquez, Raúl Alarcón, Francisco Escobar, Ximena Duprat and Alejandro Paredes in field trips, and Esteban Contreras and Carolina Reyes for mosquito identification. We are grateful to Professor Sonia Pérez and Juan Sergio for invaluable field work.

\section{REFERENCES}

Alaniz, A.J., Carvajal, M.A., Bacigalupo, A., Cattan, P.E. 2019. Global spatial assessment of Aedes aegypti and Culex quinquefasciatus: A scenario of Zika virus exposure. Epidemiology and Infection 147. DOI: 10.1017/ S0950268818003102.

Almiron, W.R., Brewer, M.E. Winter Biology of Culex pipiens quinquefasciatus Say, (Diptera: Culicidae) from Córdoba, Argentina. Mem Inst Oswaldo Cruz 91(5): 649-654.

Bhakat, S., Karubiu, W., Jayaprakash, V., Soliman, M.E.S. 2014. A perspective on targeting non-structural proteins to combat neglected tropical diseases: Dengue, West Nile and Chikungunya viruses. European Journal of Medicinal Chemistry. DOI: 10.1016/j.ejmech.2014.10.010. 
Barbet-Massin, M., Jiguet, F., Albert, C.H., Thuiller, W. 2012. Selecting pseudo-absences for species distribution models: how, where and how many? Methods in Ecololgy and Evolution 3(2): 327-338.

Beaumont, L.J., Gallagher, R.V., Thuiller, W., Downey, P.O., Leishman, M.R., Brault, A.C. 2009. Changing patterns of West Nile Virus transmission: altered vector competence and host susceptibility. Veterinary Research 40: 43. DOI: 10.1051/vetres/2009026

Bradley, C.A., Gibbs, S.E.J., Altizer, S. 2008. Urban land use predicts west Nile virus exposure in songbirds. Ecological Applications 18: 1083-1092. DOI: 10.1890/07-0822.1

Broennimann, O., Fitzpatrick, M.C., Pearman, P.B., Petitpierre, B., Pellissier, L., Yoccoz, Bueno Marí, R., Rueda, J., Bernués, A., Lacomba, I., Jiménez, R. 2008. Contribución al conocimiento de las poblaciones larvarias de culícidos (Díptera, Culicidae) presentes en el "Marjal dels Moros" (Valencia). Boletín de la Asociación Española de Entomología 32: 351-365.

Carvajal, M.A., Faúndez, E.I. 2018. First Record of Aedes albifasciatus in Magallanes Region, Chile. Journal of the American Mosquito Control Association 34: 117-119. DOI: $10.2987 / 18-6744.1$.

Chancey, C., Grinev, A., Volkova, E., Rios, M. 2015. The global ecology and epidemiology of West Nile Virus. BioMed Research International 1: 20. http//dx.doi. org/10.1155/2015/376230

Figueroa, D.P., Scott, S., González, C.R., Veloso, C., Canals, M. 2016. Assessing the larval niche of Culex pipiens in Chile. International Journal of Mosquito Research 3(4): 11-16.

Figueroa, D.P., Scott, S., Hamilton-West, C., González, C.R., Canals, M. 2015. Mosquitoes: disease vectors in context of climate change in Chile. Parasitologia Latinoamericana 64(2): 42-53.

Gardner, A.M., Hamer, G.L., Hines, A.M., Newman, C.M., Walker, E.D., Ruiz, M.O. 2012. Weather variability affects abundance of larval Culex (Diptera: Culicidae) in storm water catch basins in suburban Chicago. Journal of Medical Entomology 49: 270-276.

Geery, P., Holub, R. 1989. Seasonal abundance and control of Culex spp. in catch basins in Illinois. Journal of American Mosquito Control Association 5(4): 537-540.

Harbach, R.E. 2012. Culex pipiens: Species versus species complex-taxonomic history and perspective. Journal of American Mosquito Control Association 28(4 Suppl): 1023

González, C.R., Jercic, M.I., Muñoz, L. 2005. Los culícidos de Chile: (Díptera: Culicidae). Acta Entomológica Chilena 29: 31-35.

González, C.R., Mac-Lean, M. 2008. Diptera, pp. 291-234.
In: Canals, M, Cattan, P.E. (Eds) Zoología médica II Invertebrados. Editorial Universitaria, Santiago.

González, C.R., Rada, V. 2015. Culex pipiens Linnaeus (Diptera: Culicidae): Características generales, antecedentes biológicos y distribución en Chile. Parasitología Latinoamericana 64(1): 41-44.

González, C.R., Reyes, C., Rada-Chaparro, V., Saldarriaga-Córdoba, M. 2017. A new species of Aedes Meigen subgenus Ochlerotatus Lynch Arribálzaga (Diptera: Culicidae) from the coastal wetlands of the desert in northern Chile: Morphological and molecular identification. Zootaxa 4273: 31-49.

Gubler, D.J. 2007. The Continuing Spread of West Nile Virus in the Western Hemisphere. Clinical Infectious Diseases 45: 1039-1046. DOI: 10.1086/521911

Harbach, R.E. 2011. Classification within the cosmopolitan genus Culex (Diptera: Culicidae): The foundation for molecular systematics and phylogenetics research. Acta Tropica 120: 1-14.

Hernández, R.I., Bravo, L.L., Morón, D.M., Armas, E., Girón, B., Aponte, C. 2009. El Virus del Nilo Occidental: Revisión. Revista del Instituto Nacional de Higiene "Rafael Rangel" 40: 44-56.

Hernandez, E., Torres, R., Joyce, A.L. 2019. Environmental and Sociological Factors Associated with the Incidence of West Nile Virus Cases in the Northern San Joaquin Valley of California, 2011-2015. Vector-Borne and Zoonotic Diseases. DOI: 10.1089/vbz.2019.2437

IPCC. 2014. Climate Change 2014: Synthesis Report. Contribution of Working Groups I, II and III to the Fifth Assessment Report of the Intergovernmental Panel on Climate Change. Pachauri, R.K., Meyer, L.A. (Eds) Geneva, Switzerland. URL: https://www.ipcc.ch/report/ar5/syr/ Accessed: May 1, 2015.

Kamal, M., Kenawy, M.A., Rady, M.H., Khaled, A.S., Samy, A.M. 2018. Mapping the global potential distributions of two arboviral vectors Aedes aegypti and Ae. albopictus under changingclimate. PLoS ONE 13(12): e0210122. URL: https://doi.org/10.1371/journal.pone.0210122

Kilpatrick, A.M. 2011. Globalization, land use, and the invasion of West Nile virus. Science 334: 323-327.

Kumar, S., Neven, L.G., Yee, W.L. 2014. Evaluating correlative and mechanistic niche models for assessing the risk of pest establishment. Ecosphere 5: 1-23.

Lebl, K., Brugger, K., Rubel, F. 2013. Predicting Culex pipiens/ restuans population dynamics by interval lagged weather data. Parasites and Vectors 6: 129-140.

Liu, C., Berry, P.M., Dawson, T.P., Pearson, R.G. 2005. Selecting thresholds of occurrence in the prediction of species distributions. Ecography 28(3): 385-393. 
Maciá, A., García, J.J., Campos, R.E. 1997. Seasonal variation of three Culex species (Díptera: Culicidae) and its parasites and pathogens in Punta Lara, Buenos Aires, Argentina. Revista de Biologia Tropical 44-45: 267-275.

McMichael, A.J., Lindgren, E. 2011. Climate change: present and future risks to health, and necessary responses. J Intern Med 270(5): 401-413. DOI: 10.1111/j.13652796.2011.02415.x

Paaijmans, K.P., Imbahale, S.S., Thomas, M.B., Takken, W. 2010. Relevant microclimate for determining the development rate of malaria mosquitoes and possible implications of climate change. Malaria Journal 9: 196. URL: https://doi. org/10.1186/1475-2875-9-196

Paz, S., Semenza, J.C. 2013. Environmental drivers of West Nile Fever epidemiology in Europe and Western Asia-a review. International Journal of Environmental Research and Public Health 10: 3543-3562.

Phillips, S.J., Anderson, R.P., Schapire, R.E. 2006. Maximum entropy modeling of species geographic distributions. Ecological Modelling 190: 231-259.

Phillips, S.J., Dudík, M. 2008. Modeling of species distributions with maxent: new extensions and a comprehensive evaluation. Ecography 31: 161-175.

Pradier, S., Lecollinet, S., Leblond, A. 2012. West Nile virus epidemiology and factors triggering change in its distribution in Europe. Scientific and Technical Review of the Office International des Epizooties (Paris) 31(3): 829844.

Riahi, K., Rao, S., Krey, V., Cho, C., Chirkov, V., Fischer, G., Kindermann, G., Nakicenovic, N., Rafaj, P. 2011. RCP 8.5 - A scenario of comparatively high greenhouse gas emissions. Climatic Change 109(1-2): 33.

Salazar, M.J., Moncada, L.I. 2004. Ciclo de vida de Culex quinquefasciatus Say, 1826 (Díptera: Culicidae) bajo condiciones no controladas en Bogotá. Biomédica 24: 385-392.
Sallam, M.F., De Xue, R., Pereira, R.M., Koehler, P.G. 2016. Ecological niche modeling of mosquito vectors of West Nile virus in St. John's County, Florida, USA. Parasites \& Vectors 9: 371-384.

Sallam, M.F., Michaels, S.R., Riegel, C., Pereira, R.M., Zipperer, W., Lockaby, BG, Koehler, P.G. 2017. Spatio-Temporal Distribution of Vector-Host Contact (VHC) Ratios and Ecological Niche Modeling of the West Nile Virus Mosquito Vector, Culex quinquefasciatus, in the City of New Orleans, LA, USA. International Journal of Environmental Research and Public Health 14: 892. DOI: 10.3390/ijerph14080892

Samy, A.M., Elaagip, A.H., Kenawy, M.A., Ayres, C.F.J., Peterson, A.T., Soliman, D.E. 2016. Climate change influences on the global potential distribution of the mosquito Culex quinquefasciatus, vector of West Nile Virus and Lymphatic Filariasis. PLoS ONE 11(10): e0163863. DOI: 10.1371/ journal.pone.0163863

Warren, D.L., Glor, R.E., Turelli, M. 2008. Environmental niche equivalency versus conservatism: Quantitative approaches to niche evolution. Evolution 62: 2868-2883.

Weaver, S.C.L., Reisen, W.K. 2010. Present and future arboviral threats. Antiviral Research 85: 328-345.

Wiens, J.J., Graham, C.H. 2005. Niche conservatism: integrating evolution, ecology and conservation biology. Annual Review Ecology Evolution and Systematics 36: 519-539.

Wiese, D., Escalante, A.A., Murphy, H., Henry, K.A., GutierrezVelez, V.H. 2019. Integrating environmental and neighborhood factors in MaxEnt modeling to predict species distributions: A case study of Aedes albopictusin southeastern Pennsylvania. PLoSONE 14(10): e0223821. URL: https://doi.org/10.1371/journal.pone.0223821

Zorello, G., Cezar, M., Garkauskas, D., Mureb, M.A. 2012. Spatial distribution of arboviral mosquito vectors (Diptera: Culicidae) in vale do ribeira in the south-eastern Brazilian Atlantic forest. Cuadernos de Saude Publica 28: 229-238.

Received: 18.01 .2020

Accepted: 12.03.2020 